\title{
«Новый город» на страницах периодической печати США (по материалам Магнитогорска 1930-х гг.)
}

\author{
Макарова Н.Н., Трофимов А.Е. \\ Магнитогорский государственный технический университет им. Г.И. Носова, \\ Россия, 455000, г. Магнитогорск, пр. Ленина, 38 \\ E-mail: makarovanadia@mail.ru
}

\begin{abstract}
Аннотация. Советский проект в самом широком смысле понятия привлекал внимание как в момент его реализации, так и выступает предметом пристального внимания современных исследователей. В период форсированной индустриализации Магнитогорск - город, строительство которого началось в степях Южного Урала, - представлял собой образец «нового города», созданного на новом «пустом» месте, город, лишенный истории и прошлого, город, где возможно построить новое общество. Именно так советская пропаганда преподносила образ Магнитогорска как в пределах Советского Союза, так и за рубежом. Журнал «СССР на стройке» экспортировал пропагандистские идеи и образ «нового города» в капиталистический мир. В данной статье авторы на основе комплекса разнообразных исторических источников (делопроизводственные документы, источники личного происхождения и периодическая печать), в русле комплексного подхода и метода «плотного описания» анализируют проблему отражения истории создания Магнитогорска в периодической печати США. Основным историческим источником в данной работе выступили американские газеты «The Atlanta Constitution», «The Patterson morning call», «The modern view», «Nashville Banner», «Daily Free-Lance», «Reno gazette-journal», «Public opinion», «The Yonkers Herald», «The Cincinnati Enquirer», «News-Journal», The Decatur daily review», «California Eagle», «The Terrill Record», «The American Guardian», «The Times Dispatch», «Star-Phoenix», «The evening news», «The Kansas City Times», «The Wisconsin Jewish Chronicle», «Santa Rosa Republican». Ключевой вывод авторов состоит в том, что образ Магнитогорска в периодике США не был однородным и во многом зависел от идеологической направленности самого издания. Однако спектр проблем, который нашел отражение в периодической печати, был разнообразным и включал как вопросы социально-бытового обслуживания первостроителей, так и проблематику инженерных решений при реализации строительства металлургического предприятия.
\end{abstract}

Ключевые слова: «Новый город», СССР, США, индустриализация, периодическая печать, Магнитогорск.

Для цитирования: Макарова Н.Н., Трофимов А.Е. 2021. «Новый город» на страницах периодической печати США (по материалам Магнитогорска 1930-х гг.). Via in tempore. История Политология. 48 (4): 871-882. DOI: 10.52575/2687-0967-2021-48-4-871-882.

\section{«New city» in US periodical press (at the instigation of Magnitogorsk, 1930s.)}

\author{
Nadezhda N. Makarova, Andrei E. Trofimov \\ Nosov Magnitogorsk State Technical University, \\ 38 Lenina St., Magnitogorsk 455000, Russia \\ E-mail: makarovanadia@mail.ru
}

\begin{abstract}
The Soviet project in the broadest sense of the concept attracted attention both at the time of its implementation, and now as the subject of close attention of modern researchers. During the period of forced industrialization, Magnitogorsk, a city which construction began in the steppes of the Southern Urals, was an example of a «new city» created on a new «empty» place, a city devoid of history and the past, a city where it
\end{abstract}


is possible to build a new society. This is how Soviet propaganda presented the image of Magnitogorsk both within the Soviet Union and abroad. The magazine «USSR at the construction site» exported propaganda ideas and the image of the «new city» to the capitalist world. In this article, the authors analyze the problem of reflecting the history of the creation of Magnitogorsk in the US periodical press on the basis of a complex of various historical sources (office documents, sources of personal origin and periodicals), in line with an integrated approach and the method of «thick description». The main historical source in this work were the American newspapers «The Atlanta Constitution», «The Patterson morning call», «The modern view», «Nashville Banner», «Daily Free-Lance», «Reno gazette-journal», «Public opinion», «The Yonkers Herald», «The Cincinnati Enquirer», «News-Journal», The Decatur daily review», «California Eagle», «The Terrill Record», «The American Guardian», «The Times Dispatch», «Star-Phoenix», «The evening news», «The Kansas City Times», «The Wisconsin Jewish Chronicle», «Santa Rosa Republican». The key conclusion of the authors is that the image of Magnitogorsk in the US periodicals was not homogeneous and largely depended on the ideological orientation of the publication itself. However, the range of problems that were reflected in the periodical press was diverse and included both issues of social and consumer services for firsttime builders and the problems of engineering solutions in the implementation of the construction of a metallurgical enterprise.

Keywords: «New city», USSR, USA, industrialization, periodicals, Magnitogorsk.

For citation: Makarova N.N., Trofimov A.E. 2021. «New city» in US periodical press (at the instigation of Magnitogorsk, 1930s.). Via in tempore. History and political science. 48 (4): 871-882 (in Russian). DOI: $10.52575 / 2687-0967-2021-48-4-871-882$.

\section{Введение}

В ходе форсированной индустриализации на карте Советского Союза возникали новые города и промышленные предприятия, призванные преодолеть техникоэкономическое отставание СССР от стран Европы и США и обеспечить страну независимой технической базой. Магнитогорск был одним из таких первенцев сталинской индустриализации. Место для строительства завода и города было выбрано не случайно: в недрах горы Магнитной были сосредоточены запасы железной руды. Магнитогорск занимает уникальное географическое положение, поскольку расположен в двух частях света в Европе и в Азии. Левобережье города характеризуется активным рельефом, прежде всего горой Магнитной, правый берег имеет спокойный ландшафт. Обилие природных ресурсов предопределило значимость города и его активную роль в обеспечении страны металлом.

С начала строительства Магнитка стала амбициозным проектом, призванным продемонстрировать возможности построения «нового города», лишенного исторического прошлого. Значительные объемы капиталовложений, привлечение иностранных специалистов, работа агитаторов и пропагандистов по стране и за ее пределами сформировали образ промышленного гиганта. Всесоюзная стройка привлекала внимание не только простых советских людей, стремившихся получить в крупном городе работу по специальности, достойную заработную плату и бытовые условия. Даже иностранцы интересовались Магнитостроем и его успехами. В город ехали американские, немецкие, венгерские рабочие в поисках лучшей доли. Зарубежная периодическая печать активно освещала события, происходившие в городе и на стройке металлургического завода.

Все вышеперечисленное позволяет задаться вопросом о том, как зарубежные газеты освещали всесоюзную стройку, насколько успешной ее считали за рубежом, наконец, как сами иностранные газеты объясняли интерес своих граждан к Советскому Союзу и Магнитогорску. Американская пресса наиболее активно освещала указанные проблемы. Кроме того, обращение к периодической печати США 1930-х гг. позволяет внести вклад в изучение советско-американских отношений (которые традиционно вызывают интерес мировой общественности). Обе державы - СССР и США - были важными геополитиче- 
скими центрами и оказывали существенное влияние на мировую политику XX в. Одновременно с индустриализацией и началом строительства Магнитогорска в США началась Великая депрессия, что вынуждало население искать новые места и возможности для заработка. Одним из центров привлечения рабочих стал Советский Союз. Выбранная тема позволяет выявить причины, благодаря которым рабочие стремились попасть именно на строительство Магнитогорска. Помимо этого, на основе интервью рабочих мигрантов в печатных изданиях можно выявить новые сведения об условиях жизни разных категорий населения во время масштабного строительства.

Выбор хронологических рамок исследования объясняется повышенным интересом к Советскому Союзу в 1930-е гг., который связан с поиском новых мест работы вследствие Великой депрессии, а также с формированием и развитием Советского Союза как промышленного конкурента США.

\section{Историография проблемы}

Историография вопроса довольно обширна и условно может быть поделена на несколько блоков. Во-первых, исследования, посвященные советско-американским отношениям и формированию образа СССР в указанный период. В советской историографии этот вопрос был неразрывно связан с идеологическими штампами в силу политического и административного надзора. В.К. Фураев проанализировал аспекты взаимоотношений между СССР и США, уделил внимание анализу антисоветских стереотипов [Фураев, 1964]. Г.Н. Цветков осветил в своей работе борьбу различных политических сил США по вопросам повестки относительно СССР [Цветков, 1971]. В.И. Касьяненко анализировал мнение американского общества о советском государстве [Касьяненко, 1987]. Э.А. Иванян уделял особое внимание внутриполитическим процессам в СССР и их влиянию на формирование образа страны [Иванян, 1996]. Коллективизация и пятилетки в американском общественном сознании изучал К.Т. Тихий [Тихий, 2000]. Б.М. Шпотов исследовал различные аспекты привлечения иностранных специалистов и иностранного капитала для строительства новых промышленных центров в ходе индустриализации [Шпотов, 2003, 2005, 2007]. На современном этапе в историографии не так много исследований, посвященных вопросам восприятия индустриализации в американском обществе. Так, работа О.О. Резаненко, которая на основе американской прессы и комплекса других источников, включая дипломатическую переписку и материалы советской пропаганды, проанализировала образ индустриализации советской промышленности в американском сознании 1920-1930-х гг. [Резаненко, 2016]. Главный вывод исследователя состоит в том, что методы пропаганды формирования общественного мнения в США не оказывали существенного влияния на восприятие Советского Союза.

Вторым историографическим блоком являются труды, посвященные истории Магнитогорска. В 1930-1980-е гг. было множество публикаций, посвященных строительству и функционированию города, многие из которых носят публицистический характер и имеют источниковую значимость [Макарова, 2015]. Исследование отдельных вопросов в области градостроительства Магнитогорска [Тищенко, 1932], архитектурных поисков [Пузис, 1930], развития здравоохранения [Барышев, 1976], культуры в новом городе [Кусакова, 1936; Попов, 1975] традиционно являлось объектом внимания историков. Важный этап в изучении Магнитогорска начался в 2000-е гг. благодаря функционированию центра локальной истории при кафедре истории России Магнитогорского государственного университета. Вопросами пропаганды и отражением города в фотохрониках на современном этапе занимается А.Н. Макаров [Макаров, 2012]. Л.П. Спасова исследует отдельные вопросы, связанные с адаптацией иностранных специалистов к реалиям советской жизни, опираясь на пример Магнитостроя [Спасова, 2010, 2011]. 


\section{Источниковая база и методы исследования}

Источниковая база исследования представлена американскими газетами 1930-х гг. Именно пресса являлась основным каналом информации. В случае с американскими изданиями зачастую не было единой информационной повестки, что позволяет выявить различные мнения и позиции общества. Поиск источников осуществлялся с помощью сервиca «newspapers.com», в котором публикуются оцифрованные газеты. Всего было найдено и проанализировано 1008 публикаций, в которых так или иначе затрагивался Магнитогорск. Следует уточнить, что в большинстве случаев публиковались лишь сведения о том, сколько тонн той или иной продукции было выпущено в городе. Часто одна и та же статья публиковалась в разных газетах (иногда более 10 раз).

Методологической основой исследования является принцип историзма, что обеспечивает всесторонний и объективный анализ источникового материала. Хронологический и сравнительно-исторический методы позволяют рассмотреть все события в их развитии и взаимной связи, проследить эволюцию образа Магнитогорска в американской прессе. Реализация задач исследования достигается посредством использования сочетания междисциплинарного, функционального, ретроспективного и проблемно-хронологического методов.

\section{Результаты исследования}

Интерес к Магнитогорску в американской прессе не был стабильным (рис. 1). Самое значительное число упоминаний о городе в СМИ США относится к 1931 и 1932 гг., что обусловлено завершением первой пятилетки в СССР в целом и всплеском интереса к Магнитострою, где для иностранных специалистов предлагали особые условия работы.

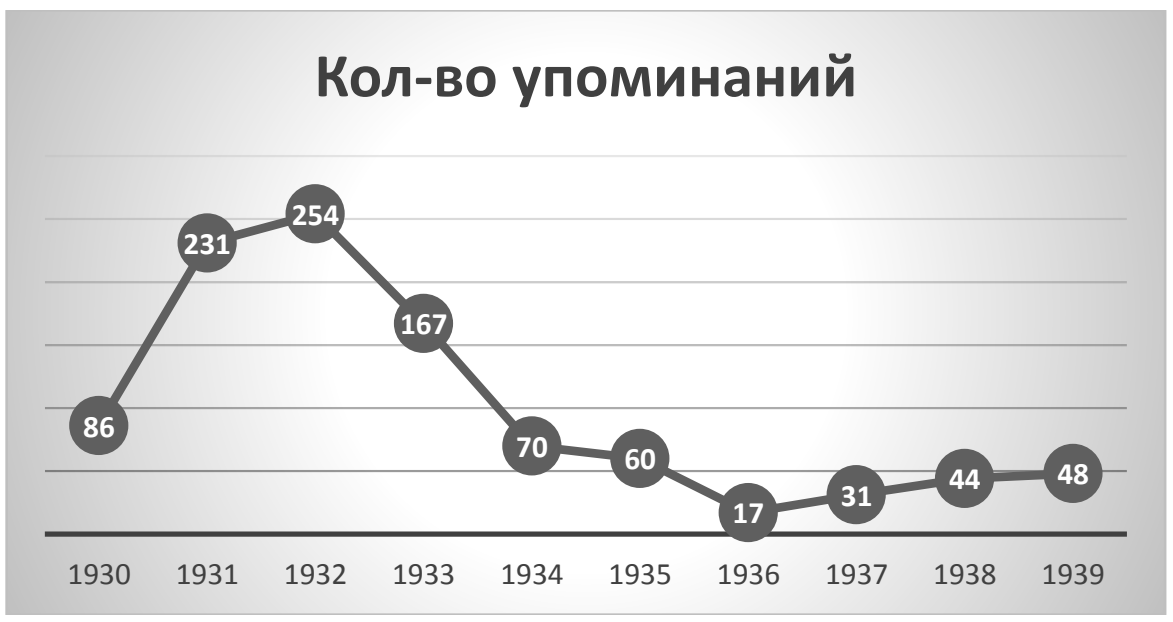

Рис. 1. Количество упоминаний Магнитогорска (по данным портала newspapers.com)

Fig. 1. The number of mentions of Magnitogorsk (according to the portal newspapers.com)

Интерес к Магнитогорску подтверждает тот факт, что город упоминался в американских газетах в два раза чаще, чем Кузнецк и Челябинск. Именно Магнитогорску посвящены наиболее развернутые статьи, другие же промышленные центры упоминались, как правило, только в контексте сообщений об индустриализации советской промышленности.

Все публикации в американских СМИ о Магнитогорске можно с некоторой долей условности сгруппировать следующим образом: США как помощник и партнер СССР; публикации о планах развития Магнитки как «города нового типа»; интервью с американскими рабочими о Магнитострое и информация о быте различных категорий населения; сведения о происшествиях.

Первые публикации о сотрудничестве СССР и США в сфере строительства металлургического завода появились в печати в конце 1920-х гг. Так, в газете «The Atlanta Con- 
stitution» от 21 декабря 1928 г. сказано, что «Шестнадцать техников сейчас находятся в пути, чтобы руководить строительством сталелитейного завода в Тобольске, Магнитогорске, Кривом Роге» [Americans and Russia. The Atlanta Constitution. 1928. December 21. P. 6]. Интересен эмоциональный фон публикации. Автор писал о сближении двух стран: «от Америки должно прийти спасение. Ни одна из европейских наций по той или иной причине не смогла удовлетворить потребности великого славянского мира <..> Но теперь надежда на Соединенные Штаты» [Americans and Russia..., 1928. December 21. Р. 6.]. Автор также считает, что для нового поколения советских граждан Америка наделена «ореолом романтики» [Americans and Russia..., 1928. December 21. P. 6].

17 марта 1930 г. в ряде американских газет появились сведения о том, что «американские инженеры получили контракт на советский промышленный объект стоимостью 237 млрд долларов» [Steel city is plan of soviet. Dayton Daily News. March 17, 1930. P. 23.]. Авторы указывали, что масштабы завода будут такими же, как у завода в городе Гэри. Также газеты анонсировали встречу американских инженеров и советской делегации во главе с В.А. Смольяниновым.

20 июля 1930 г. в газете «Nashville Banner» вышла статья под названием «Американские личности в российской программе» [Americans figure in Russia's program. Nashville Banner. July 20, 1930. Р. 4]. В ней рассматривали американцев, задействованных в советской индустриализации. «Российская индустриализация в том виде, в каком она существует сегодня, несомненно, является самой большой вещью такого рода, когда-либо задуманной, действующей в рамках так называемой пятилетки», - писал автор [Americans figure in Russia's program..., 1930. Р. 4]. В статье сообщалось о 45 заключенных контрактах с американскими производителями и участии более 600 американцев в строительстве. Оценка индустриализации в СССР как попытка создания «из ничего, так сказать, высокоиндустриального общества» не была слишком высокой. Далее автор публикации указал, что «если эта схема сработает, то перемены в русском народе <...> могут быть колоссальными» [Americans figure in Russia's program..., 1930. Р. 4] и высказал опасения по поводу будущего СССР: «Если коммунистам удастся удержать народ в своей мертвой хватке и, таким образом, использовать его для осуществления своих планов мировой революции, мир может в конечном итоге столкнуться с несогласованными событиями. Остается определиться, заняты ли Соединенные Штаты, Германия и другие страны изобретением Франкенштейна» [Americans figure in Russia's program..., 1930. Р. 4].

25 января 1931 г. в газете «Daily Free-Lance» была опубликована большая статья, посвященная Магнитогорску, под названием «'Гэри России” возвышается рядом с железной горой; американские инженеры подгоняют 20000 советских рабочих» [«Gary of Russia» rises near mountain of iron; american engineers prod 20000 soviet workers. Henryetta Daily Free-Lance, January 25, 1931. Р. 6]. Автор писал, что пока город состоит «из лачуг и палаток», что строительство было бы невозможным без помощи американских специалистов и пропаганды патриотизма [«Gary of Russia» rises near mountain of iron..., January 25, 1931. P. 6].

Иногда публиковались заметки относительно конкуренции США и СССР в промышленности. Издатели стремились показать техническое преимущество Америки на долгие годы вперед. Так, 15 июля 1931 г. в «Reno gazette-journal» была опубликована статья «Не видят угрозы в российских товарах» [Sees no threat in russian goods. Reno GazetteJournal. July 15, 1931. P. 5]. В ней были приведены размышления Бейкера, компания которого руководила строительством металлургического комбината в Магнитогорске. Он подчеркнул, что металлургическая промышленность СССР не сможет удовлетворить потребности Европы и США и не будет международным конкурентом в сфере промышленных товаров: «Расстояния велики, а транспорт в России беден. Я убежден, что пройдет много лет, прежде чем Россия сможет позаботиться о своих собственных первичных потребностях» [Sees no threat in russian goods..., 1931. P. 5]. 
17 марта 1932 г. в газете «Public opinion» была опубликована статья «Советский стальной город начинает производить чугун» [Soviet steel town begins to make pig iron. Public Opinion. March 17, 1932. P. 3]. В ней приводится отчет главы фирмы Mckee \& Co советскому правительству о строительстве комбината в Магнитогорске: «Производство чугуна является убедительным доказательством того, что плановые и строительные работы последних двух лет были выполнены должным образом и успешно» [Soviet steel town begins to make pig iron..., March 17, 1932. Р. 3]. Американский инженер уточнил, что пока производительность печи составляет 500 тонн в день и не достигнет 1000 тонн, русские не станут более опытными. «Это создает прецедент в советской промышленной практике»- говорилось в статье. Авторы указывали и на перспективы магнитогорского комбината: «Печь № 2 находится в завершающей стадии достройки и должна быть запущена ранней весной. Только эти два агрегата способны производить 2000 тонн чугуна в сутки, что на $15 \%$ превысило бы производительность» [Soviet steel town begins to make pig iron..., March 17, 1932. Р. 3]. Также авторы отметили, что «сырье оказалось даже лучше, чем ожидалось» [Soviet steel town begins to make pig iron..., March 17, 1932. P. 3].

20 августа 1932 г. в газете «The eagle» вышла большая статья, посвященная Магнитогорску [City of Magnitogorsk giant of Soviet five-year plan; city of iron is built in three years. The Eagle. August 20, 1932, Р. 6]. Автор сообщал, что Магнитка является одним из самых показательных мест, которые только можно посетить в Советском Союзе, что город - это «смесь амбиций, движущей энергии, неуверенного и некачественного исполнения, масштабного строительства, тяжелых и примитивных условий жизни, идеализма и безжалостности» [City of Magnitogorsk giant of Soviet five-year plan; city of iron is built in three years..., August 20, 1932, Р. 6]. Основное внимание в статье было уделено перспективам развития города и доказательству тезиса, что Магнитогорску до завода Гэри еще далеко. По поводу жизни рабочих говорилось, что все они живут в бараках, а единственное комфортабельное жилье построено специально для иностранных специалистов.

К 1934 г. о Магнитогорске знало большое число американцев, а газеты сообщали, что новые индустриальные города необходимо посетить, чтобы понять советскую действительность. Для американских туристических компаний это стало дополнительной возможностью заработать. Так, 1 мая 1934 г. в газете «The Pittsburgh press» было опубликовано предложение: «американо-российская торговая палата организует обследование новых гигантских советских индустрий протяженностью 5000 миль. Этот пробный тур покинет Москву 2 июля и посетит Магнитогорск, Челябинск, Новосибирск, Новокузнецк» [Soviet markets at first hand. The Pittsburgh Press. May 1, 1934. P. 5].

В целом американские издатели не упускали возможности возвысить авторитет США в глазах обычных граждан. При этом Америка становилась чуть ли не единственным и самым важным партнером СССР для реализации масштабных промышленных проектов.

Второй тип статей связан с формированием представлений о широких возможностях на Магнитострое для приезжих рабочих. Единая информационная повестка в публикациях отсутствовала. В условиях Великой депрессии привлекательный образ «нового города», в котором много рабочих мест, мотивировал американцев ехать в Магнитогорск. Так, 4 января 1930 г. в газете «The morning call» в статье «Прогнозы финансистов» [Predictions by financiers in Russia and Belgium only ones which sound decidedly optimistic tone in united press symposium. The Morning Call. January 4, 1930. P. 3] сообщалось, что лишь в СССР и Бельгии «оптимистично» развивается экономика [Predictions by financiers in Russia and Belgium only ones which sound decidedly optimistic tone in united press symposium..., January 4, 1930. P. 3]. В публикации были зафиксированы цифры: производительность промышленности должна увеличиться на 32 \%, а заработная плата - на 9 \%. Такие показатели экономического роста не могли не стимулировать американских рабочих, оставшихся без средств к существованию, отправиться в СССР, в том числе и в Магнитогорск. Данная статья была перепечатана под другими названиями в газетах США, например, в 
«Intelligencer journal» [European experts of finance see difficult year. Intelligencer Journal. January 4, 1930. Р. 14] и «The Atlanta constitution» [European business expects good year. The Atlanta Constitution. January 5, 1930. P. 22].

Отдельного внимания заслуживают газетные статьи Ю. Лайонса, который в начале 1930-х гг. активно поддерживал промышленное строительство и пропагандировал советские ценности в американских изданиях. Так, 3 апреля 1930 г. американские газеты выпустили его статью «Россия строит синтетический город» [Russia building synthetic city. The Hastings Daily Tribune. April 3, 1930. Р. 3]. Ю. Лайонс писал, что «Российское правительство планирует вернуться к социалистическим идеям античной Спарты, социальная и коммунальная жизнь будут обеспечены на 100 \%» [Russia building synthetic city..., April 3, 1930. P. 3]. Интересны представления автора о жизни в городе: «До 16 лет все дети будут воспитываться и содержаться самой общиной, в яслях, детских садах, в школах и лицеях. Они будут жить вдали от своих родителей, хотя будут поощряться тесные отношения посредством частных взаимных визитов» [Russia building synthetic city..., April 3, 1930. Р. 3]. Ю. Лайонс пытался предсказать роль женщины в городе нового типа и отмечал, что они будут освобождены от домашних обязанностей и займут место наравне с мужчинами в новой индустриальной жизни. Согласно Ю. Лайонсу, архитектурно город должен состоять из «жилых коммун» [Russia building synthetic city..., April 3, 1930. Р. 3], а каждый житель будет иметь собственную идеальную комнату. Еда для всего города должна готовиться и распределяться из «одной огромной кухни» [Russia building synthetic city..., April 3, 1930. P. 3].

12 июля 1930 г. в газете «The Yonkers Herald» вышла статья Ю. Лайонса под названием «Центральный комитет Коммунистической партии выносит предупреждение против слишком резкого вмешательства» [Central committee of the communist party issues a warning against too drastic interference. The Yonkers Herald, July 12, 1930. P. 11]. В публикации говорилось, что ЦК КПСС выступил против вмешательства в личную и домашнюю жизнь рабочих: «взгляды на такие вопросы [от ЦК КПСС] равносильны приказу» [Central committee of the communist party issues a warning against too drastic interference..., July 12, 1930. P.11]. «Предложение о немедленном налаживании семейной жизни, об изъятии детей у родителей, об упразднении отдельных кухонь были восприняты прессой всего несколько месяцев назад с большим энтузиазмом» [Central committee of the communist party issues a warning against too drastic interference..., July 12, 1930. Р. 11]. В статье критиковали М. Сабсовича и Н. Ларина, авторов данных нововведений в сфере социального устройства: «Он [И.В. Сталин - авт.] указывает на Ларина и Сабсовича, руководителей этих поспешных революций повседневной жизни, как на людей, виновных в крайне неразумных, фантастических и потом опасных попытках одним прыжком преодолеть все препятствия на пути к социалистическому устройству жизни» [Central committee of the communist party issues a warning against too drastic interference..., July 12, 1930. P. 11].

Анализируя эти газетные статьи, можно сделать вывод, что в американском сознании Магнитогорск должен был закрепиться как перспективный проект, в котором любой человек может жить во благо новых идей и ценностей. Это обстоятельство во многом способствовало прибытию американцев в Магнитогорск.

Следующая группа публикаций в американских СМИ представляет различные интервью американских рабочих, участвовавших в строительстве города. Многие интервью заранее анонсировались в газетах. Так, 9 апреля 1932 г. в ряде газет Миннеаполиса появились сведения о том, что некий Ф.У. Дэвис, управляющий опытной станцией в университете, опишет Россию такой, какой он ее видел во время работы на Магнитострое [«U» Mine expert to speak on Russ. Star Tribune. April 9, 1932. P. 7].

17 июля 1932 г. в газете «News-Journal» была опубликована статья «Эксперт рассказывает о России» [Shelby expert tells of Russia. News-Journal. July 17, 1932. P. 2]. В ней Ж. А. Габриэль делился своими впечатлениями о годичной поездке в СССР. Начинался рассказ с описания дороги до Магнитогорска («Поездка заняла четыре дня и была совершена в 
поезде совсем другого типа, чем в Америке») и погодных условий («экстремальную погоду на протяжении всего путешествия») [Shelby expert tells of Russia..., July 17, 1932. P. 2]. Ж.А. Габриэль был шокирован температурой воздуха минус 37 градусов по шкале Цельсия, из-за чего нельзя было набрать воды в колодце: «шесть футов под землей были заморожены» [Shelby expert tells of Russia..., July 17, 1932. P. 2]. В Магнитогорске автор поселился в американской деревне недалеко от завода и приступил к обязанностям инженера-консультанта, отвечающего за канализацию. Говоря об условиях жизни в России, Ж.А. Габриэль заявил: «условия жизни низшего рабочего класса в Соединенных Штатах лучше, чем лучшее, что может предложить Россия. Однако русские делали для американцев все, что могли, и относились к ним даже лучше, чем к высшим российским чиновникам» [Shelby expert tells of Russia..., July 17, 1932. Р. 2]. Автор отметил, что они жили в частных домах и питались в ресторане. Продолжение истории Ж.А. Габриэля [Work Moves Slowly. News-Journal. July 18, 1932. Р. 2] было посвящено медленным темпам строительства [Work Moves Slowly..., July 18, 1932. Р. 2] и недостаткам расположения завода [Work Moves Slowly..., July 18, 1932. P. 2]. В третьей части рассказа автор объяснял странности в костюме магнитогорцев погодными условиями: «Зимой, когда термометр держался около 29 градусов ниже нуля, конторские рабочие и инженеры были вынуждены носить кожаные пальто, подбитые собачьим мехом, высокие воротники, меховые шапки и кожаные сапоги или "малинки", валенки без подошвы» [Weather cause of oddities in Russian dress. News-Journal. July 19, 1932. P. 3].

Отдельный блок посвящен этике поведения магнитогорских рабочих во время принятия пищи. Автор указывал, что в рестораны [столовые - авт.] все ходят в рабочей одежде. «Рабочие ограничиваются в еде лишь самым необходимым. Они редко используют больше одной тарелки. Русская посуда и одежда практичны так же, как и в Америке, вместо магазинов в главном деловом районе, как у нас в Соединенных Штатах, одежда и продукты питания доставляются и передаются в руки распределительных магазинов» [Weather cause of oddities in Russian dress..., July 19, 1932. Р. 3]. Ж.А. Габриэль указывал на низкое качество хлеба, недостаток кисломолочных продуктов: «Одним из самых дефицитных продуктов в продуктовой линейке России является молоко и его продукт - сливочное масло» [Weather cause of oddities in Russian dress..., July 19, 1932. P. 3].

Четвертая часть рассказа Ж.А. Габриэля была опубликована 20 июля 1932 г. под названием «Образование - одна из самых больших забот России» [Weather cause of oddities in Russian dress..., July 19, 1932. Р. 3]. По мнению автора, власти делали все возможное для просвещения своего народа, чтобы обеспечить производство квалифицированными кадрами и отказаться от помощи американцев: «Существуют репетиторы для домашнего обучения по вечерам и занятия через день в главном зале или оперном театре в окрестностях Магнитогорска» [Weather cause of oddities in Russian dress..., July 19, 1932. P. 3]. Ж.А. Габриэль сообщал о роли религии в образовании и общественной жизни: «Одним из наименее упоминаемых предметов в России является вопрос религии. Ни одна религия не преподается в школах, немногие церкви открыты для богослужения» [Weather cause of oddities in Russian dress..., July 19, 1932. Р. 3].

Автор говорил о том, что в Магнитогорске рабочие трудятся сверх нормы [Weather cause of oddities in Russian dress..., July 19, 1932. Р. 3] и сообщал о зарплатах отдельных работников: «Чертежники и детальщики получают около 250 рублей $(\$ 179,50$ в американских деньгах) в месяц. Опытные мужчины получают 500 рублей (359 долларов) и более в месяц. Инженеры, принадлежащие к правительственной партии, ограничиваются 500 рублями в месяц, но им предоставляются особые льготы в отношении транспорта, большего количества продовольствия и в большинстве случаев обеспечиваются зимним обмундированием» [Weather cause of oddities in Russian dress..., July 19, 1932. P. 3].

12 мая 1933 г. в газете «California Eagle» вышла заметка, в которой сварщик Дж. Скотт сообщал, что «несмотря на все сообщения, нет принудительного труда, нет безработицы, нет долгих часов в опасных отраслях, как заставила бы нас поверить амери- 
канская пресса» [As I see it. California Eagle. May 12, 1933. Р. 10]. Тем самым он опроверг многочисленные сообщения о трудностях на строительстве Магнитогорского комбината. Следует понимать, что Дж. Скотт был сторонником коммунистической идеологии и верил в идею построения «светлого будущего». Однако по образу Магнитогорска в американском сознании могла ударить статья «Заключенные в Советского Союзе платят за свой труд», опубликованная на страницах газеты «The American Guardian» 18 января 1935 г. По словам автора, их практически невозможно отличить от других работников, разница состоит лишь в том, что они живут в специально отведенных бараках.

Вышеприведенные газетные статьи демонстрируют перечень фактов, на основе которых складывалось представление американцев о Магнитогорске. Первоначально американцев привлекали с помощью особых условий труда и им создавали комфортные условия для жизни. Однако социально-бытовые условия, о которых советские строители могли только мечтать, для иностранцев оказались непривлекательными. Кроме того, обещанная высокая заработная плата часто оставалась только обещанием.

В отдельную группу публикаций можно сгруппировать многочисленные заметки о происшествиях - необычных явлениях в жизни новостройки. Так, например, в американских СМИ очень популярной была тема эмансипации женщин. 10 февраля 1932 г. в газете «The Times Dispatch» была опубликована статья «Женщины будут руководить Советским Союзом в следующей войне». В качестве доказательства особой роли женщины в Магнитогорске зарубежные газеты перепечатали заметку о том, что бригада мужчин не смогла справиться с производственными задачами, а женская бригада перевыполнила план на $105 \%$ [Women will run Soviet in next war while the men fight. The Times Dispatch. February 10, 1932. Р. 9]. Любопытство у американского читателя вызвали такие случаи на Магнитострое, как низкое качество работы почтовой службы (почтальон просто сжигал письма, чтобы не разносить их адресатам)» [Mail burned by Russian clerks. Star-Phoenix. Friday, March 13, 1931. Р. 13], торжества по поводу выплавки 900 тонн чугуна [Sidelights in the news of capitals. The Evening News. March 30, 1932. P. 6], переживания магнитогорцев о том, что в срок не запустят домну [Sidelights in the news of capitals..., March 30, 1932. P. 6], использование ручного труда и отсутствие механизации при работе на котловане [Huge Plant by manpower. The Charleston Daily Mail. July 25, 1932. P. 4].

С началом второй пятилетки в американской прессе чаще стали появляться публикации, формирующие негативный образ Магнитогорска. Так, статья под названием «Грязные сибирские гиганты говорят, что им нужен воздух» [Sick Siberian «Giants» are said to need air. The Norman Transcript. October 3, 1933. Р. 3] была переиздана несколько раз. В ней редакторы газет ссылались на слова Г.К. Орджоникидзе, отметили медленные темпы строительства, значительные потери материалов и рабочей силы, плохие жилищные условия и некачественное питание. Религиозный и национальный вопросы в американских СМИ также использовались для укрепления негативного образа Магнитогорска. Например, публиковались статьи о преследованиях церковнослужителей [European letter. Santa Rosa Republican. December 22, 1931. P. 14].

\section{Заключение}

Таким образом, публикации в американской прессе, посвященные Магнитогорску, представляют собой богатый комплекс источников для изучения различных вопросов: советско-американские отношения в 1930-е гг., вопрос миграции специалистов в СССР вследствие экономического кризиса и депрессии, образ Магнитогорска в контексте индустриализации. В 1930-е гг. США формировали образ спасителя Советского Союза в вопросах индустриализации, подчеркивали особую роль американских компаний, специалистов и рабочих в создании металлургического завода. При этом отмечалось, что СССР не сможет стать конкурентом США в промышленной сфере. Основными мотивационными 
факторами прибытия в Магнитогорск американцев являлась неблагоприятная социальноэкономическая ситуация в США в связи с депрессией и активная пропаганда «нового города», отсутствия безработицы и достойных условий жизни и труда в Магнитогорске. Положительное отношение к городу как к потенциальному месту работу сохранялось лишь до 1933 г. Далее оценки в прессе сильно изменились в худшую сторону. Среди основных причин, побудивших отказаться рабочих ехать в Советский Союз, можно назвать отказ выплачивать заработную плату «валютой», начало восстановления экономики после депрессии, наличие негативного опыта пребывания в СССР некоторых американцев и увеличение количества советских специалистов в различных сферах деятельности. Образ Магнитогорска в контексте индустриализации тоже претерпевал постоянные изменения. В основном его формировали люди, дававшие интервью американских изданиям после посещения Магнитогорска и знакомства с социалистическими идеями. Личность автора интервью, его уникальный социальный опыт пребывания в Магнитогорске оказывали существенное влияние на оценку обстановки в промышленном городе. Ярким примером таких оценок могут быть публикации Дж. Скотта, настроенного прокоммунистически, и Ю. Лайонса, который формировал исключительно положительный образ города «нового» типа (свои взгляды в отношении СССР он изменил только в 1934 г.).

\section{Благодарности}

Исследование выполнено при финансовой поддержке РФФИ в рамках научного проекта № 21-09-43032 «Повседневная жизнь и эмоциональный режим промышленного города (по материалам Магнитогорска 1930-1950-х гг.)»

\section{Список литературы}

1. Иванян Э.А. 1996. Кремль против Белого Дома. США: Экономика, политика, идеология. (2): 26-33.

2. Касьяненко В.И. 1987. Правда и ложь о Стране Советов. М., Мысль, 336.

3. Макаров А.Н. 2012. Советский индустриальный фоторепортаж 1930-х гг. как средство стереотипизации массового сознания. Проблемы истории, филологии, культуры. (3/37): 111-121.

4. Макарова Н.Н. 2015. Город Магнитогорск как объект исторических исследований (к постановке проблемы). Проблемы истории, филологии, культуры. (4): 156-166.

5. Резаненко О.О. 2016. Американская пресса о советской индустриализации в 1920-1930-е годы. Самарский научный вестник. (2/15): 115-120.

6. Спасова Л.П. 2011. Адаптация иностранных специалистов к реалиям советской жизни: опыт Магнитостроя. Проблемы истории, филологии, культуры. (2/32): 213-222.

7. Спасова Л.П. 2010. Магнитострой и «Мак-Ки»: столкновение деловых культур. Вестник Пермского университета. Серии: история и политология. (1/12): 100-109.

8. Тихий К.Т. 2000. Американское общественное мнение о Советском государстве, 1921-1933 гг., Владивосток, 2000, 471.

9. Фураев В.К. 1964. Советско-американские отношения. 1917-1939. М., Мысль, 1964, 319.

10. Цветков Г.Н. 1971. Шестнадцать лет непризнания: Политика США в отношении Советского государства в 1917-1933 гг. Киев, Изд-во Киев. ун-та, 1971, 243.

11. Шпотов Б.М. 2007. Взаимовосприятие американцев и русских в годы первой пятилетки (по материалам прессы и деловой переписки). Отечественная история. (4): 135-140.

12. Шпотов Б.М. 2005. Использование опыта США при организации и управлении строительством в СССР в 1920-е - 1930-е гг. Рос. журнал менеджмента. (3/1): 145-162.

13. Шпотов Б.М. 2003: Политика использования западных технологий как фактор создания крупной индустрии в СССР. Проблемы теории и практики управления. (4): 119-122.

14. «Gary of Russia» rises near mountain of iron; American engineers prod 20000 soviet workers. Henryetta Daily Free-Lance, January 25, 1931.

15. Americans and Russia. The Atlanta Constitution. 1928. December 21.

16. As I see it. California Eagle. May 12, 1933. P. 10. 
17. Central committee of the communist party issues a warning against too drastic interference. The Yonkers Herald, July 12, 1930.

18. City of Magnitogorsk giant of Soviet five-year plan; city of iron is built in three years. The Eagle. August 20, 1932.

19. European business expects good year. The Atlanta Constitution. January 5, 1930.

20. European experts of finance see difficult year. Intelligencer Journal. January 4, 1930.

21. European letter. Santa Rosa Republican. December 22, 1931.

22. Mail burned by Russian clerks. Star-Phoenix. Friday, March 13, 1931.

23. Predictions by financiers in Russia and Belgium only ones which sound decidedly optimistic tone in united press symposium. The Morning Call. January 4, 1930.

24. Russia building synthetic city. The Hastings Daily Tribune. April 3, 1930.

25. Sees no threat in russian goods. Reno Gazette-Journal. July 15, 1931.

26. Shelby expert aided in Russia by interpreter. News-Journal. July 22, 1932.

27. Shelby expert telss of Russia. News-Journal. July 17, 1932.

28. Sick Siberian «Giants» are said to need air. The Norman Transcript. October 3, 1933.

29. Sidelights in the news of capitals. The Evening News. March 30, 1932.

30. Soviet markets at first hand. The Pittsburgh Press. May 1, 1934.

31. Soviet steel town begins to make pig iron. Public Opinion. March 17, 1932.

32. Steel city is plan of soviet. Dayton Daily News. March 17, 1930.

33. Weather cause of oddities in Russian dress. News-Journal. July 19, 1932.

34. Women will run Soviet in next war while the men fight. The Times Dispatch. February 10, 1932.

35. Work Moves Slowly. News-Journal. July 18, 1932.

\section{References}

1. Ivanjan Je.A. 1996. Kreml' protiv Belogo Doma [Kremlin vs. White House]. SShA: Jekonomika, politika, ideologija. (2): 26-33.

2. Kas'janenko V.I. 1987. Pravda i lozh' o Strane Sovetov [Truth and lies about the Land of the Soviets]. M., Mysl', 336.

3. Makarov A.N. 2012. Sovetskij industrial'nyj fotoreportazh 1930-h gg. kak sredstvo stereotipizacii massovogo soznaniya [Soviet industrial photo report of the 1930s. as a means of stereotyping mass consciousness]. Problemy istorii, filologii, kul'tury. (3/37): 111-121.

4. Makarova N.N. 2015. Gorod Magnitogorsk kak ob"ekt istoricheskikh issledovaniy (k postanovke problemy) [The city of Magnitogorsk as an object of historical research (to problem statement)]. Journal of Historical, Philological and Cultural Studies. (4): 156-166.

5. Rezanenko O.O. 2016. Amerikanskaja pressa o sovetskoj industrializacii v 1920-1930-e gody [American press on Soviet industrialization in the 1920s and 1930s]. Samarskij nauchnyj vestnik. (2/15): $115-120$.

6. Spasova L.P. 2011. Adaptacija inostrannyh specialistov k realijam sovetskoj zhizni: opyt Magnitostroja [Adaptation of foreign specialists to the realities of Soviet life: the experience of Magnitostroi]. Problemy istorii, filologii, kul'tury. (2/32): 213-222.

7. Spasova L.P. 2010. Magnitostroj i «Mak-Ki»: stolknovenie delovyh kul'tur [Magnetostroy and McKee: a clash of business cultures]. Vestnik Permskogo universiteta. Serii: istorija i politologija. (1/12): 100-109.

8. Tihij K.T. 2000. Amerikanskoe obshhestvennoe mnenie o Sovetskom gosudarstve, 1921-1933 gg. [American Public Opinion about the Soviet State, 1921-1933]. Vladivostok, 471.

9. Furaev V.K. 1964. Sovetsko-amerikanskie otnoshenija 1917-1939 [Soviet-American relations. 1917-1939]. M., Mysl', 319.

10. Cvetkov G.N. 1971. Shestnadcat' let nepriznanija: Politika SShA v otnoshenii Sovetskogo gosudarstva v 1917-1933 gg. [Sixteen Years of Non-Recognition: US Policy Toward the Soviet State in 1917-1933] Kiev, Izd-vo Kiev. un-ta, 243.

11. Shpotov B.M. 2007. Vzaimovosprijatie amerikancev i russkih v gody pervoj pjatiletki (po materialam pressy i delovoj perepiski) [Mutual perception of Americans and Russians during the first five-year plan (based on materials from the press and business correspondence)]. Otechestvennaja istorija. (4): 135-140. 
12. Shpotov B.M. 2005. Ispol'zovanie opyta SShA pri organizacii i upravlenii stroitel'stvom v SSSR v 1920-e - 1930-e gg. [Using the US experience in organizing and managing construction in the USSR in the 1920s - 1930s.]. Ros. zhurnal menedzhmenta. (3 /1): 145-162.

13. Shpotov B.M. 2003. Politika ispol'zovanija zapadnyh tehnologij kak faktor sozdanija krupnoj industrii v SSSR [The policy of using Western technologies as a factor in the creation of a large industry in the USSR]. Problemy teorii i praktiki upravlenija. (4): 119-122.

14. "Gary of Russia» rises near mountain of iron; American engineers prod 20000 soviet workers. Henryetta Daily Free-Lance, January 25, 1931.

15. Americans and Russia. The Atlanta Constitution. 1928. December 21.

16. As I see it. California Eagle. May 12, 1933.

17. Central committee of the communist party issues a warning against too drastic interference. The Yonkers Herald, July 12, 1930.

18. City of Magnitogorsk giant of Soviet five-year plan; city of iron is built in three years. The Eagle. August 20, 1932.

19. European business expects good year. The Atlanta Constitution. January 5, 1930.

20. European experts of finance see difficult year. Intelligencer Journal. January 4, 1930.

21. European letter. Santa Rosa Republican. December 22, 1931.

22. Mail burned by Russian clerks. Star-Phoenix. Friday, March 13, 1931.

23. Predictions by financiers in Russia and Belgium only ones which sound decidedly optimistic tone in united press symposium. The Morning Call. January 4, 1930.

24. Russia building synthetic city. The Hastings Daily Tribune. April 3, 1930.

25. Sees no threat in russian goods. Reno Gazette-Journal. July 15, 1931.

26. Shelby expert aided in Russia by interpreter. News-Journal. July 22, 1932.

27. Shelby expert telss of Russia. News-Journal. July 17, 1932.

28. Sick Siberian «Giants» are said to need air. The Norman Transcript. October 3, 1933.

29. Sidelights in the news of capitals. The Evening News. March 30, 1932.

30. Soviet markets at first hand. The Pittsburgh Press. May 1, 1934.

31. Soviet steel town begins to make pig iron. Public Opinion. March 17, 1932.

32. Steel city is plan of soviet. Dayton Daily News. March 17, 1930.

33. Weather cause of oddities in Russian dress. News-Journal. July 19, 1932.

34. Women will run Soviet in next war while the men fight. The Times Dispatch. February 10, 1932.

35. Work Moves Slowly. News-Journal. July 18, 1932.

Конфликт интересов: о потенциальном конфликте интересов не сообщалось.

Conflict of interest: no potential conflict of interest related to this article was reported.

\section{ИНФОРМАЦИЯ ОБ АВТОРАХ}

Макарова Надежда Николаевна, кандидат исторических наук, доцент, заместитель директора по научной работе Института гуманитарного образования Магнитогорского государственного технического университета им. Г.И. Носова, г. Магнитогорск, Россия

Трофимов Андрей Евгеньевич, студент Института гуманитарного образования Магнитогорского государственного технического университета им. Г.И. Носова, г. Магнитогорск, Россия

\section{INFORMATION ABOUT THE AUTHORS}

Nadezhda N. Makarova, Candidate of Historical Sciences, Associate Professor, Deputy Director for Research, Institute of Humanitarian Education, Magnitogorsk State Technical University named after G.I. Nosov, Magnitogorsk, Russia

Andrey E. Trofimov, student of the Institute of Humanitarian Education, Magnitogorsk State Technical University named after G.I. Nosov, Magnitogorsk, Russia 